\title{
Seasonal Variation and Hydro-chemical Characterization of Manchalapur Lake Quality for Drinking and Agricultural Purposes
}

\author{
Francis Kwarteng $^{1 *}$, Umapathy Satishkumar ${ }^{1}$, Moddi Nemichandrappa ${ }^{1}$, \\ Banda Maheshwara Babu ${ }^{1}$ and Veeresh Hogarnal ${ }^{2}$
}

${ }^{1}$ Department of Soil and Water Engineering, ${ }^{2}$ Department of Soil Science and Agricultural Chemistry, College of Agriculture, University of Agricultural Sciences, Raichur, P. B. No. 329, Raichur 584102, Karnataka, India

*Corresponding author

\section{A B S T R A C T}

In this study the hydrochemical characteristics of the Manchalapur tank water or lake was analysed for its suitability for domestic, fish rearing and irrigation purposes. A total of 10 water samples each were drawn from the inlet, outlet and two other locations in the water spread area of the tank and analysed for TDS, $\mathrm{pH}, \mathrm{EC}, \mathrm{BOD}_{5}, \mathrm{COD}$, major ions, detergent and pathogen contamination in three distinct seasons, viz. pre-monsoon, monsoon and

\section{Keywords}

Manchalapur Lake, Water quality,

Salinity, Domestic use, Irrigation, Fish propagation, Raichur city.

\section{Article Info}

Accepted:

10 September 2017

Available Online:

10 November 2017 post-monsoon, based on standard methods. The concentration of pollutants had varied within these seasons with TDS, pH, EC, COD, and the major ions measuring the highest in the pre-monsoon season when tank had received undiluted sewage from the Raichur city. The order of dominance of ions in water samples of this study area is $\mathrm{Na}^{+}>\mathrm{Ca}^{2+}>\mathrm{Mg}^{2+}>$ $\mathrm{K}^{+}$and $\mathrm{Cl}^{-}>\mathrm{SO}_{4}{ }^{2-}>$ Nitrate $>\mathrm{PO}_{4}{ }^{3-}>\mathrm{HCO}_{3}{ }^{-}>\mathrm{CO}_{3}{ }^{2-}$ as estimated in the pre-monsoon season, and $\mathrm{Na}^{+}>\mathrm{Ca}^{2+}>\mathrm{K}^{+}>\mathrm{Mg}^{2+}$ and $\mathrm{Cl}^{-}>\mathrm{SO}_{4}{ }^{2-}>$ Nitrate $>\mathrm{PO}_{4}{ }^{3-}>\mathrm{HCO}_{3}{ }^{-}>\mathrm{CO}_{3}{ }^{2-}$ in both the monsoon and post-monsoon seasons. According to $\mathrm{pH}$ values, tank water is alkaline during all three sampling seasons. The weighted water quality index was used to assess the suitability of tank water for domestic purposes. The $\sum$ WQI was estimated as 24, 30 and 26 in the pre-monsoon, monsoon and post-monsoon seasons respectively, indicating a critical water quality condition and thus raising high objection against the use of the tank water for drinking purpose. However, the tank water was found most suitable for irrigation in the monsoon season as compared to other seasons since it poses no or limited salinity and sodium hazards. This is corroborated by TDS, EC, major ions, SAR and Na\% values measured in the monsoon season which are all within permissible limits. On the other hand, high $\mathrm{BOD}_{5}$, COD, excess in NPK present in water system, surfactants and pathogen contamination rendered tank water unsupportive for fish and thus may impair aquatic life. Hence, other than irrigation (even that only in the monsoon season), the Manchalapur tank water is unsuitable for drinking and fish propagation.

\section{Introduction}

Among the various environmental challenges that India faces this century, better management of water quality is of high priority as there is increased stress on surface water sources due to population pressure. The major threat to the sustainability of surface water systems is pollution. Pollution affects the quality of water and limits its multiple uses. Besides, the rate of water system pollution increases as population increases 
due to increasing urbanization and growing urban wastewater flows due to the expansion of water supply and sewerage services and/or defunct or inadequate treatment facilities (CPCB, 2010). The Manchalapur Lake is a case in point of this scenario.

The Manchalapur Lake, also known as the Manchalapur tank, historically served the Manchalapur village as main source for domestic purposes, agriculture and fishery. However, in recent past the tank has been the main disposal point of sewage from the Raichur city of Karnataka state of India. This means that under current situation of municipal sewage pollution, the quality of tank water could be affected and thus, limiting its suitability for multiple uses.

The composition of wastewater contains organic matter, nutrients (nitrogen, phosphorus, and potassium), inorganic matter (dissolved minerals), toxic chemicals and pathogens (Hussain et al., 2002). The indirect use (i.e. use of water from water bodies polluted by wastewater) of wastewater could have a greater potential for health problems such as ailments including fever, headache, skin and stomach problems, among other communicable diseases (Shende et al., 2000; Srinivasan and Reddy, 2009). The uses of sewage-fed water for aquaculture and irrigation are well documented in Indian societies (Strauss and Blumenthal, 1990; Buechler et al., 2002; Bhamoriya, 2004; Minhas and Samra, 2004; Huibers et al., 2005; Suutari, 2006; Kaur et al., 2012; Palrecha et al.,2012). The use of wastewater for irrigation is basically seen as a fertility issue (Rutkowski et al., 2007), however, unregulated wastewater irrigation practices could have a range of associated problems that may in some cases outweigh the benefits (Hussain et al., 2002; Amerasinghe et al., 2013). While the presence of biodegradable organics would impart higher biochemical oxygen demand (BOD) and chemical oxygen demand (COD) and would have deleterious effects on aquatic life (Hussain et al., 2002) .Therefore, it requires that water for drinking, irrigation and fishery must meet certain standards.

Hence, the overarching goal of this study is to assess the quality of Manchalapur tank water under current situation of municipal sewage pollution, evaluate how the water quality varies under the three different seasons (i.e. pre-monsoon, monsoon and post-monsoon) and determine the suitability of tank water against its historical uses i.e. drinking, irrigation and fishery.

\section{Description of study area}

The Manchalapur Lake spreads adjacent to the Manchalapur village and is located at about $10 \mathrm{~km}$ away from the Raichur city of the Karnataka state of India. The area of investigation spreads around 981 hectares including its catchment, command and water spread area. Manchalapur is situated in the north-eastern dry zone (Zone-2) of Karnataka located at $16^{\circ} 14^{\prime} \mathrm{N}$ latitude and $77^{\circ} 19^{\prime} \mathrm{E}$ longitude and at an elevation of 380 metres above mean sea level. The weather of the study area remains almost dry throughout the year, a very hot summer with mean monthly maximum temperature of $46.15^{\circ} \mathrm{C}$ in May and a minimum of $16.6^{\circ} \mathrm{C}$ in December, with very low and erratic precipitation with an average annual rainfall of $621 \mathrm{~mm}$. The crops grown in the study area include paddy, cotton, sunflower, red gram, beans among other horticultural crops and vegetables.

\section{Sampling and laboratory methods}

For analysis of various water parameters AR Grade chemicals (Merck, India) were used. All glassware and other sample containers 
were rinsed with double-distilled water and sterilized prior to use. The seasons chosen for sampling were pre-monsoon, monsoon and post monsoon for the $2014 / 2015$ period. 10 water samples were taken each from the inlet, outlet and two different locations in the water spread area of the tank (represented as WS-I for first location in water spread area and WSII for second location in water spread area). Using standard methods for the examination of water and wastewater as per APHA, 1998, the water samples were analysed for most water quality influencing physicochemical parameters, which included $\mathrm{pH}, \mathrm{EC}$, TDS, nitrogen, phosphorus, potassium, bicarbonates, chloride, sulphate, sodium, calcium, magnesium, COD, BOD, coliform and surfactants. Pearson's correlation coefficient (r) was also worked out to judge the strength and direction of relation between various parameters and reported at 0.01 and 0.05 levels of significance using Sigmastat 3.5 .

\section{Results and Discussion}

\section{Seasonal variation in Manchalapur tank water quality}

\section{Tank water quality in the pre monsoon season}

The $\mathrm{pH}$ values measured in the pre-monsoon season ranged between 7.2 and 8.84 with an average approximately 8.4 which indicates that the tank water is alkaline in the premonsoon season. EC of tank water ranges from 1.45 to $1.72 \mathrm{dS} / \mathrm{m}$ with an average of $1.525 \mathrm{dS} / \mathrm{m}$. TDS measured averagely 992 $\mathrm{mg} / \mathrm{l}$ with the highest recorded at the outlet. This indicates that the amount of soluble inorganic substances tend to be higher at the outlet than any other location during this season. The values of parameters measured at the inlet, two separate locations at the water spread area and outlet of the tank is given in the Table 1. The dominant ions in the tank water is in the order of $\mathrm{Na}^{+}>\mathrm{Ca}^{2+}>\mathrm{Mg}^{2+}>\mathrm{K}^{+}$ for cations and $\mathrm{Cl}^{-}>\mathrm{SO}_{4}{ }^{2-}>$ Nitrate $>\mathrm{PO}_{4}{ }^{3-}$ $>\mathrm{HCO}_{3}{ }^{-}>\mathrm{CO}_{3}{ }^{2-}$ for anions. All the cations measured the highest at the inlet of the tank as well as available plants nutrients (NPK) and $\mathrm{HCO}_{3}{ }^{-}$. During the pre-monsoon season, the tank received undiluted sewage flow from the Raichur city. Thus, it can be concluded that the inflow received contributed to the inorganic contaminants of tank water but was also rich in beneficial plant nutrients. Unlike the rest of the ions, chloride and sulphate contamination was bulged at the water spread areas and the outlet. Anthropological activities like fertiliser and pesticide applications in fields close to these areas would have also contributed to the significant increment. This would have also resulted in higher chemical and biochemical oxygen demands recorded at the water spread areas and the outlet of the tank.

Surfactants are widely used in household products. After use, surfactants as well as their products are mainly found in the Manchalapur tank water through discharge of sewage from the Raichur city. Surfactants measured in receiving flow recorded the highest, $5.5 \mathrm{ppm}$ LAS, and is measured as twice or more as compared to other locations of the tank. Even though the proximity of the villagers' laundry to the tank, which is about 50 metres away downstream, may contribute to surfactant contamination by runoff, the major source is the receiving flow from the Raichur city.

\section{Tank water quality in the monsoon season}

The onset of monsoon is mostly from July to October and characterised by heavy downpour. The authors in a companion study, Kwarteng et al., (2016), analysed the probable quantity of sewage inflow from Raichur city and estimated rainfall-runoff from the 
catchment. They estimated the dilution ratio (as runoff as a fraction of sewage in percentage) as approximately $18.8 \%$ and concluded that this would likely have significant effect on tank water quality due to this dilution of sewage by rainfall-runoff. The results of parameters measured in the monsoon season with their mean values are given in Table 2.

The $\mathrm{pH}$ values measured ranged from 7.23 at the inlet to 8.21 with an average of approximately 7.68. EC was also measured the highest at the inlet of tank as $1.66 \mathrm{dS} / \mathrm{m}$ and lowest at the outlet which measured 1.36 $\mathrm{dS} / \mathrm{m}$. TDS, however, ranged from $360 \mathrm{mg} / \mathrm{l}$ at the inlet to $560 \mathrm{mg} / \mathrm{l}$ at the water spread area II. The dominant ions measured in the monsoon season in the tank water samples is in the increasing order $\mathrm{Na}^{+}>\mathrm{Ca}^{2+}>\mathrm{K}^{+}>$ $\mathrm{Mg}^{2+}$ for cations and $\mathrm{Cl}^{-}>\mathrm{SO}_{4}{ }^{2-}>$ Nitrate $>$ $\mathrm{PO}_{4}{ }^{3-}>\mathrm{HCO}_{3}{ }^{-}>\mathrm{CO}_{3}{ }^{2-}$ for anions. Average value of sodium, calcium, magnesium had decreased in concentration from that measured in pre-monsoon by $76.84 \%, 10.06$ $\%$ and $6.85 \%$ respectively. Anion concentrations such as chloride, sulphate and $\mathrm{HCO}_{3}{ }^{-}+\mathrm{CO}_{3}{ }^{2-}$ on the other hand had also decreased by $31 \%, 20.73 \%$ and $12.94 \%$ respectively. Mean concentrations of TKN, phosphate and potassium had also increased by $85.36 \%, 21.14 \%$ and $102.99 \%$ respectively; the highest being percentage increase in potassium. Surfactant contamination was also on the increase ranging from 2.9 to $7.2 \mathrm{ppm}$ LAS.

\section{Tank Water Quality in the post-monsoon season}

The chemical parameters measured in the post-monsoon season are given in Table 3 . The dominant ions as measured in the postmonsoon season are $\mathrm{Ca}^{2+}>\mathrm{Na}^{+}>\mathrm{K}^{+}>\mathrm{Mg}^{2+}$ for cations and $\mathrm{Cl}^{-}>\mathrm{SO}_{4}{ }^{2-}>$ Nitrate $>\mathrm{PO}_{4}{ }^{3-}$ $>\mathrm{HCO}_{3}{ }^{-}>\mathrm{CO}_{3}{ }^{2-}$ for anions in that order. The average concentrations of dissolved solids and ions measured in the post-monsoon season had all experienced a significant increment in concentration from those measured in the monsoon season with the exception of magnesium which rather decreased by about $32.9 \%$.

The percentage increase in sodium recorded the highest as $105.3 \%$ and a marginal increment in calcium by $0.746 \%$. Percentage increment in concentrations of potassium, chloride, sulphates, TKN, phosphates and bicarbonate are as follows: $9.98 \%, 28 \%$ and $23.38 \%, \quad 3.27 \%, \quad 77.79 \%$ and $2.02 \%$ respectively. Surfactant contamination, however, recorded a decrease by $25.98 \%$ from the previous season.

The tank water is alkaline in all the three sampling seasons. The average $\mathrm{pH}$ was measured highest in the pre-monsoon season and it could be as a result of higher dissolved salts and low water volume. This also accounted for higher $\mathrm{pH}$ measured in postmonsoon season as compared to in monsoon season where $\mathrm{pH}$ actually recorded the least. Total Dissolved Solids in tank water originates from natural sources, sewage and runoff from catchment. The values are generally higher in the pre-monsoon season and this could be due to stagnation of tank water and higher dissolved salts. According to Table 4 , there are statistically significant $(\alpha=$ $0.05)$ positive correlations between TDS and $\mathrm{pH}(\mathrm{r}=0.608)$. There also exist a positive correlation between $\mathrm{pH}$ and $\mathrm{Cl}(\mathrm{r}=0.802)$ and $\mathrm{pH}$ and $\mathrm{SO}_{4}{ }^{2-}(\mathrm{r}=0.721)$ at the 0.01 level. TDS on the other hand also correlated significantly with $\mathrm{Cl}^{-}(\mathrm{r}=0.713)$ and $\mathrm{Na}^{+}(\mathrm{r}=$ 0.823 ) at 0.01 los. The highest value of EC is also measured highest in the pre-monsoon season, followed by monsoon season and post monsoon season. This variation may be due to high evaporation of tank water during the summer season and dilution of salinity during 
rainy season (Al-Khashman et al., 2013). EC in tank water correlates positively with $\mathrm{Ca}^{2+}(\mathrm{r}$ $=0.629)$ at the 0.05 level and with $\mathrm{Mg}^{2+}(\mathrm{r}=$ 0.935 ) at the 0.01 level.

Higher dissolved ions during the pre-monsoon season, followed by post monsoon season and monsoon season which is corroborated by EC and TDS accounts for why $\mathrm{Cl}^{-}, \mathrm{SO}_{4}{ }^{2-}, \mathrm{HCO}_{3}{ }^{-}$, water soluble $\mathrm{Ca}^{2+}$ and $\mathrm{Mg}^{2+}$ and $\mathrm{Na}^{+}$ recorded the highest in pre-monsoon season. Lower water volume and higher dissolution of salts from bed rocks may also be attributed to why these anions and cations recorded the highest in the pre-monsoon season. Aside the sewage inflow, sulphate concentration present in the water samples could also be due to atmospheric deposition from acid rain, human and animal waste, and farming activities (Souligny et al., 2001).

The chloride concentration was measured the highest in the pre-monsoon season (360 - 592 $\mathrm{mg} / \mathrm{l})$, followed by post monsoon season (398 $-489 \mathrm{mg} / \mathrm{l})$ and least in monsoon season (302 - $411 \mathrm{mg} / \mathrm{l}$ ). The higher concentration of chloride in the pre-monsoon season is perhaps as a result of human excrement, chlorides consumed (commonly $\mathrm{NaCl}$ ) which is a constituent of domestic sewage inflow and the evaporation of water in the tank and may not necessarily be the chlorination of the municipal water supply (Al-Khashman et al., 2013). Sodium for instance was very high during the pre-monsoon season and is because sewage contains organic contents, faeces (as evidenced by exceeding limits of faecal coliform), bio-degradable and nonbiodegradable chemicals from various domestic activities. On the other hand, the decrease in ion concentrations from premonsoon to monsoon season could be as a result of dilution of tank water by rainfallrunoff. Carbonate concentration in all areas in all three sampling seasons was very low. The ion concentrations measured correlates positively with each other at the two different levels as given in Table 4.

The significant positive and negative correlation among some of the hydrochemical parameters as presented in Table 4 is indications of the possibility of pollutant load from a common source or a source causing pollution having similar effects on parameters that are correlated. Thus, a particulate increasing an ion concentration for example would also result in an increment in the other parameter where there exists a significant positive correlation and likewise in case of a decrement. Positive correlations between two parameters indicate that they tended to increase or decrease together whereas negative correlation indicating that one parameter increased as the other decreased.

$\mathrm{BOD}_{5}$ was highest during monsoon due to higher inflow, and high decomposition of organic matter as a result of higher oxygen concentration because of low temperature, followed by pre-monsoon and least in postmonsoon season. COD on the other hand was high during summer due to lower water volume and dissolved ions. There exist a positive correlation between $\mathrm{COD}$ and $\mathrm{Cl}(\mathrm{r}=$ 0.588 ) at 0.05 los. The inflow of domestic wastewater, agricultural runoff (due to fertiliser use), animal waste and detergentfilled sewage is the probable source for NPK concentration. TKN, phosphates and potassium all showed a similar trend as they were recorded highest in the post-monsoon season, followed by monsoon and premonsoon seasons. Comparatively higher inflow of both sewage and runoff from agricultural land during the monsoon and post monsoon seasons (highest here due to relatively higher decomposition of organic matter) accounted for higher NPK unlike during the pre-monsoon season when only sewage inflow and less or no application of fertiliser are expected. 


\section{Drinking water quality}

The water quality index is regarded an important tool in assessing the overall status of water quality in a very simple manner and for easy interpretation (Mahuya et al., 2001; Gupta et al., 2003). Nine important water quality indicators were selected which are widely used in drinking water analyses. The derivation of this cumulated WQI involves assigning of unit index to each parameter $\left(W_{i}\right)$; rating of each parameter $\left(V_{r}\right)$; product of assigned unit index and rating $\left(W_{i}{ }^{\times} V_{r}\right)$; and then ranking of water quality based on the index table.

In assigning index to each parameter, the following equation was used:

$W_{i} \alpha \frac{1}{V_{i}}=\frac{k}{V_{i}}$

Where $k$ is constant of proportionality and estimated as:

$$
k=\frac{1}{\sum_{i=0_{n}} 1 / V_{i}}
$$

As most studies have revealed, the weights of the assessment indicators were assigned based on their relative importance to overall water quality (Tyagi et al., 2013), and the weighting method is as follows:

$$
\omega_{i}=\frac{q_{i}}{\sum_{i=1}^{L} q_{i}} \quad i=1,2, \ldots . ., \quad L
$$

Where $\omega_{i}$ and $q_{i}$ are the weight and the importance parameter of the $i^{\text {th }}$ indicator, respectively. $L$ is the amount of indicators. $q_{i}$ is a dimensionless number with a domain, where $1,2,3,4$, and 5 denote very little, little, average, great, and greatest importance, respectively (Semiromi et al., 2011). And finally the WQI was generated as an aggregation of the sub-indices following a weighted aggregation method using the weighted sum model as per (Semiromi et al., 2011; Srebotnjak et al., 2012).

$W Q I=\sum_{i=1}^{L} \omega_{i} \cdot Q i$

Where $Q_{i}$ is sub-index for $i$ th water quality parameter. The final step involves ranking of water quality based on the index table (Table $5)$.

The results of estimated WQI for the three sampling seasons are given in Table 6.

The estimated $Q_{i}$ for all the parameters (except for $\mathrm{pH}$ which is within permissible limit) in determining the water quality for domestic purposes were high beyond desirable limits culminating in rendering the tank water unsuitable for drinking. The concentrations of phosphate and BOD are critical which measured $Q_{i}=2.0$ and $Q_{i}=5$ respectively throughout the sampling seasons. Temperature change and excess in nitrates are among parameters with very low $Q_{i}$. The estimated $\sum \mathrm{WQI}$ for the pre-monsoon and post-monsoon seasons are 24 and 26 respectively, indicating a very bad water quality. Whereas, the quality of tank water in monsoon season is bad according to the water quality rating with estimated $\sum \mathrm{WQI}=30$.

\section{Irrigation water quality}

\section{Salinity and sodium hazards}

Water with high salinity is toxic to plants and poses a salinity hazard. Water salinity is usually measured by the TDS (total dissolved solids) or the EC (electric conductivity). Salinization in water relates to increase in TDS and overall chemical content of water. This is corroborated by the presence of 
dissolved chemical ions such as sodium, chloride, sulphates, bicarbonate and carbonate which when in excess in irrigation water, can affect soil fertility and crop productivity. However, the dissolved solids and chemical ions measured in water samples from the Manchalapur tank were below the maximum permissible limit of irrigation water (BIS, 2012). However, according to Bauder et al., (2014), chloride, especially, exceeding 350 $\mathrm{mg} / \mathrm{l}$ can cause severe problems to crops and thus tank water must be used with proper management measures. Another most influential parameter to assess salinity hazard is the EC. The primary effect of high ECof irrigation water on crop productivity is the inability of the plant to compete with ions in the soil solution for water (physiological drought). Classification of irrigation water based on EC (Raghunath, 1987) is given in Table 7 which shows that the water samples drawn from the Manchalapur tank were within permissible limit. However, prolonged use of tank water with no proper irrigation management is likely to result in accumulation of salt at the root zone of crops over time.

Concentration of sodium plays a major role in evaluating the water quality for irrigation since accumulation of sodium concentration can result in sodicity which causes swelling and dispersion of soil clays, surface crusting and pore plugging, and thus obstructs infiltration and may increase runoff. Sodicity causes a decrease in the downward movement of water into and through the soil, and actively growing plants roots may not get adequate water, despite pooling of water on the soil surface after irrigation. Although plant growth is primarily limited by the salinity level of the irrigation water, the application of water with a sodium imbalance can further reduce yield under certain soil texture conditions. The sodium hazard is the relative proportion of sodium to calcium and magnesium ions. It is usually expressed in terms of sodium adsorption ratio (SAR). SAR is calculated by (Richards, 1954),

$\mathrm{SAR}=\frac{\mathrm{Na}^{+}}{\sqrt{\frac{\mathrm{Ca}^{2+}+\mathrm{Mg}^{2+}}{2}}}$

Where the concentrations are represented in meq/l.

SAR measured from water samples are given in Table 8 which indicates very low values only in the monsoon season and thus tank water may pose no sodium hazard to soil and crops during this season.

SAR values of irrigation water less than 10 is considered to be low and suitable for irrigation but caution must be taken in cases of sodium sensitive crops especially during the post monsoon season which recorded SAR values closer to 10 . SAR measured at two sampling locations during the premonsoon ranges between 10 to 18 and the other two locations SAR ranges from 18 to 26. This is an indication that tank water may generally not be suitable for irrigation during the pre-monsoon season based on SAR.

On the other hand, as the SAR value measured in the monsoon season ranges from 4.154 to 4.496 with corresponding $\mathrm{EC}$ exceeding $1.20 \mathrm{dS} / \mathrm{m}$ at all locations, the infiltration rate should not be affected, however, since flood irrigation is generally practised by farmers, SAR value between 3 and 9 could mean that the sodium content could be toxic to plants through accumulation over time (Ayers et al., 1985).

Sodium percentage $(\mathrm{Na} \%)$ of water samples from Manchalapur tank water was calculated by Raghunath (1987), 
Table.1 Chemical characteristics of tank water measured in the pre-monsoon season

\begin{tabular}{|c|c|c|c|c|c|c|}
\hline Parameters & Unit & Inlet & WS-I & WS-II & Outlet & Mean \\
\hline $\mathrm{BOD}_{5}$ & $\mathrm{mg} / \mathrm{l}$ & 163 & 168 & 136 & 192 & 164.75 \\
\hline COD & $\mathrm{mg} / \mathrm{l}$ & 929 & 1586 & 1506 & 220 & 1060.25 \\
\hline TDS & $\mathrm{mg} / \mathrm{l}$ & 796 & 980 & 956 & 1236 & 992 \\
\hline $\mathrm{pH}$ & no unit & 7.23 & 8.75 & 8.84 & 8.72 & 8.385 \\
\hline $\mathrm{EC}$ & $\mathrm{dS} / \mathrm{m}$ & 1.72 & 1.47 & 1.46 & 1.45 & 1.525 \\
\hline Sodium & $\mathrm{mg} / \mathrm{l}$ & 136 & 128 & 108 & 116 & 122 \\
\hline Calcium & $\mathrm{mg} / \mathrm{l}$ & 88 & 70 & 67.20 & 72.80 & 74.50 \\
\hline Magnesium & $\mathrm{mg} / \mathrm{l}$ & 26 & 18 & 17.28 & 18.72 & 20 \\
\hline Potassium & $\mathrm{mg} / \mathrm{l}$ & 22.03 & 19.23 & 17.75 & 18.0 & 19.25 \\
\hline TKN & $\mathrm{mg} / \mathrm{l}$ & 38.23 & 27.57 & 23.45 & 21.85 & 27.775 \\
\hline Phosphate & $\mathrm{mg} / \mathrm{l}$ & 16.37 & 12.39 & 12.01 & 8.23 & 12.25 \\
\hline Chloride & $\mathrm{mg} / \mathrm{l}$ & 360 & 592 & 568 & 524 & 511 \\
\hline Sulphate & $\mathrm{mg} / \mathrm{l}$ & 88 & 108 & 110 & 104 & 102.5 \\
\hline $\mathrm{HCO}_{3}^{-}$ & $\mathrm{mg} / \mathrm{l}$ & 9.6 & 8.4 & 6.2 & 7.2 & 7.85 \\
\hline $\mathrm{CO}_{3}^{2-}$ & $\mathrm{mg} / \mathrm{l}$ & 0.2 & BDL & 1.2 & 1.2 & 0.65 \\
\hline Surfactant & Ppm LAS & 5.5 & 2.5 & 2.2 & 2.4 & 3.15 \\
\hline Faecal coliform & MPN/100ml & $>1600$ & 900 & 900 & 900 & - \\
\hline Total coliform & MPN/100ml & $>1600$ & 1600 & 1600 & 1600 & - \\
\hline
\end{tabular}

BDL = Below Detectable Limit

Table.2 Chemical characteristics of Manchalapur tank water measured in the monsoon season

\begin{tabular}{|c|c|c|c|c|c|c|}
\hline Parameters & Unit & Inlet & WS-I & WS-II & Outlet & Mean \\
\hline $\mathrm{BOD}_{5}$ & $\mathrm{mg} / \mathrm{l}$ & 232 & 210 & 205 & 213 & 215 \\
\hline COD & $\mathrm{mg} / \mathrm{l}$ & 434 & 446 & 304 & 394 & 394.5 \\
\hline TDS & $\mathrm{mg} / \mathrm{l}$ & 360 & 400 & 560 & 400 & 430 \\
\hline $\mathrm{pH}$ & no unit & 7.23 & 7.96 & 7.31 & 8.21 & 7.6775 \\
\hline $\mathrm{EC}$ & $\mathrm{dS} / \mathrm{m}$ & 1.66 & 1.46 & 1.40 & 1.36 & 1.47 \\
\hline Sodium & $\mathrm{mg} / \mathrm{l}$ & 32 & 28 & 26 & 27 & 28.25 \\
\hline Calcium & $\mathrm{mg} / \mathrm{l}$ & 79 & 68.6 & 53.2 & 67.2 & 67 \\
\hline Magnesium & $\mathrm{mg} / \mathrm{l}$ & 25.92 & 17.64 & 13.68 & 17.28 & 18.63 \\
\hline Potassium & $\mathrm{mg} / \mathrm{l}$ & 42.30 & 38.70 & 36.80 & 38.50 & 39.075 \\
\hline TKN & $\mathrm{mg} / \mathrm{l}$ & 65.42 & 53.90 & 48.22 & 38.40 & 51.485 \\
\hline Phosphate & $\mathrm{mg} / \mathrm{l}$ & 34.68 & 16.10 & 6.06 & 2.52 & 14.84 \\
\hline Chloride & $\mathrm{mg} / \mathrm{l}$ & 302 & 341 & 356 & 411 & 352.5 \\
\hline Sulphate & $\mathrm{mg} / \mathrm{l}$ & 79 & 82 & 84 & 80 & 81.25 \\
\hline $\mathrm{HCO}_{3}^{-}$ & $\mathrm{mg} / \mathrm{l}$ & 7.2 & 6.4 & 6.0 & 7.2 & 6.7 \\
\hline $\mathrm{CO}_{3}{ }^{2-}$ & $\mathrm{mg} / \mathrm{l}$ & BDL & 1.2 & 1.2 & 0.4 & 0.70 \\
\hline Surfactant & ppm LAS & 7.2 & 2.9 & 4.5 & 3.1 & 4.425 \\
\hline Faecal coliform & MPN/100ml & 1600 & 900 & 900 & $>1600$ & - \\
\hline Total coliform & MPN/100ml & $>1600$ & 1600 & 1600 & $>1600$ & - \\
\hline
\end{tabular}


Table.3 Chemical characteristics of Manchalapur tank water measured in the post-monsoon season

\begin{tabular}{lllllll}
\hline Parameters & Unit & Inlet & WS-I & WS-II & Outlet & Mean \\
\hline BOD $_{5}$ & $\mathrm{mg} / \mathrm{l}$ & 178 & 162 & 156 & 159 & 163.75 \\
$\mathrm{COD}$ & $\mathrm{mg} / \mathrm{l}$ & 537 & 406 & 452 & 559 & 488.5 \\
$\mathrm{TDS}$ & $\mathrm{mg} / \mathrm{l}$ & 480 & 400 & 720 & 540 & 535 \\
$\mathrm{pH}$ & $\mathrm{no} \mathrm{unit}$ & 7.10 & 7.32 & 8.54 & 8.64 & 7.90 \\
$\mathrm{EC}$ & $\mathrm{dS} / \mathrm{m}$ & 1.32 & 1.11 & 1.07 & 1.06 & 1.14 \\
Sodium & $\mathrm{mg} / \mathrm{l}$ & 65 & 61 & 51 & 55 & 58 \\
Calcium & $\mathrm{mg} / \mathrm{l}$ & 79 & 60 & 58 & 73 & 67.5 \\
Magnesium & $\mathrm{mg} / \mathrm{l}$ & 18 & 11 & 9.28 & 11.72 & 12.5 \\
Potassium & $\mathrm{mg} / \mathrm{l}$ & 41.60 & 43.10 & 43.30 & 43.90 & 42.975 \\
TKN & $\mathrm{mg} / 1$ & 68.53 & 54.36 & 48.87 & 40.91 & 53.1675 \\
Phosphate & $\mathrm{mg} / \mathrm{l}$ & 35.48 & 20.40 & 28.24 & 21.42 & 26.385 \\
Chloride & $\mathrm{mg} / \mathrm{l}$ & 398 & 451 & 467 & 489 & 451.25 \\
Sulphate & $\mathrm{mg} / \mathrm{l}$ & 81 & 99 & 98 & 123 & 100.25 \\
$\mathrm{HCO}_{3}{ }^{-}$ & $\mathrm{mg} / \mathrm{l}$ & 5.2 & 7.6 & 6.6 & 5.2 & 6.15 \\
$\mathrm{CO}_{3}{ }^{2-}$ & $\mathrm{mg} / \mathrm{l}$ & 1.2 & 1.2 & 1.2 & 2.0 & 1.4 \\
Surfactant & $\mathrm{Ppm} \mathrm{LAS}$ & 7.0 & 1.0 & 2.7 & 2.4 & 3.275 \\
Faecal coliform & $\mathrm{MPN} / 100 \mathrm{ml}$ & 900 & $>1600$ & $>1600$ & 900 & \\
Total coliform & $\mathrm{MPN} / 100 \mathrm{ml}$ & 1600 & $>1600$ & $>1600$ & 1600 & - \\
\hline
\end{tabular}

Table.4 Pearson correlation between hydro-chemical characteristics of Manchalapur tank water samples

\begin{tabular}{|c|c|c|c|c|c|c|c|c|c|c|c|c|c|c|c|}
\hline & $\mathrm{pH}$ & $\mathrm{EC}$ & TDS & $\mathrm{Cl}^{-}$ & $\mathrm{SO}_{4}{ }^{2-}$ & $\mathrm{HCO}_{3}{ }^{-}$ & TKN & $\mathrm{PO}_{4}{ }^{3-}$ & $\mathrm{Na}^{+}$ & $\mathrm{Ca}^{2+}$ & $\mathrm{Mg}^{2+}$ & $\mathrm{K}^{+}$ & $\mathrm{BOD}_{5}$ & COD & $\begin{array}{c}\begin{array}{c}\text { Surfact- } \\
\text { ants }\end{array} \\
\end{array}$ \\
\hline $\mathrm{pH}$ & 1 & & & & & & & & & & & & & & \\
\hline EC & -0.265 & 1 & & & & & & & & & & & & & \\
\hline TDS & $0.608 *$ & 0.208 & 1 & & & & & & & & & & & & \\
\hline $\mathrm{Cl}$ & $0.802 * *$ & -0.321 & $0.713 * *$ & 1 & & & & & & & & & & & \\
\hline $\mathrm{SO}_{4}^{2-}$ & $0.721 * *$ & -0.443 & 0.536 & $0.823 * *$ & 1 & & & & & & & & & & \\
\hline $\mathrm{HCO}_{3}-{ }^{--}$ & 0.0244 & 0.264 & 0.388 & 0.141 & 0.152 & 1 & & & & & & & & & \\
\hline TKN & $-0.771 * *$ & -0.124 & $-0.821 * *$ & $-0.744 * *$ & $-0.613^{*}$ & -0.427 & 1 & & & & & & & & \\
\hline $\mathrm{PO}_{4}{ }^{3-}$ & -0.405 & -0.144 & -0.367 & -0.297 & -0.134 & -0.315 & $0.729 * *$ & 1 & & & & & & & \\
\hline $\mathrm{Na}^{+}$ & 0.309 & 0.344 & $0.823^{* *}$ & $0.601 *$ & 0.472 & $0.611^{*}$ & $-0.655^{*}$ & -0.17 & 1 & & & & & & \\
\hline $\mathrm{Ca}^{2+}$ & -0.11 & $0.629^{*}$ & 0.162 & -0.156 & -0.0258 & 0.354 & -0.0986 & 0.199 & 0.483 & 1 & & & & & \\
\hline $\mathrm{Mg}^{2+}$ & -0.333 & $0.935^{* *}$ & 0.097 & -0.372 & -0.431 & 0.226 & 0.0121 & 0.0816 & 0.329 & $0.819 * *$ & 1 & & & & \\
\hline $\mathrm{K}^{+}$ & -0.428 & -0.551 & $-0.87 * *$ & -0.551 & -0.317 & -0.475 & $0.817 * *$ & 0.516 & $-0.853 * *$ & -0.34 & -0.406 & 1 & & & \\
\hline $\mathrm{BOD}_{5}$ & -0.397 & 0.409 & -0.427 & -0.683 & $-0.703^{*}$ & -0.272 & 0.419 & -0.0137 & -0.569 & 0.0701 & 0.406 & 0.299 & 1 & & \\
\hline COD & 0.383 & 0.285 & 0.453 & $0.588^{*}$ & 0.421 & 0.203 & -0.495 & -0.125 & $-0.659 *$ & 0.233 & 0.204 & $-0.637 *$ & -0.563 & 1 & \\
\hline Surfactant & $-0.682 *$ & 0.538 & -0.306 & $-0.663 *$ & $-0.648^{*}$ & -0.31 & $0.585^{*}$ & 0.521 & -0.144 & 0.433 & $0.653^{*}$ & 0.185 & 0.471 & -0.148 & 1 \\
\hline
\end{tabular}

** Correlation is significant at the 0.01 level, * Correlation is significant at the 0.05 level

Table.5 Water Quality Rating as per NSF-WQI

\begin{tabular}{ll}
\hline WQI range & Category-Rank \\
\hline $0-25$ & Very bad \\
$26-50$ & Bad \\
$51-70$ & Moderate \\
$71-90$ & Good \\
$91-100$ & Very good \\
\hline
\end{tabular}


Table.6 Weighted aggregation water quality index for the three sampling seasons

\begin{tabular}{|l|l|l|l|l|}
\hline Factor & Weight & $Q_{i \text {-pre-mon. }}$ & $Q_{i \text {-monsoon }}$ & $Q_{i \text {-post monsoon }}$ \\
\hline Dissolved Oxygen $(\%$ saturation $)$ & 0.17 & 26 & 49 & 33 \\
\hline Faecal Coliform $(\mathrm{CFU} / 100 \mathrm{~mL})$ & 0.16 & 20 & 23 & 20 \\
\hline $\mathrm{pH}$ & 0.16 & 70 & 91 & 88 \\
\hline BOD $(\mathrm{mg} / \mathrm{L})$ & 0.11 & 5 & 5 & 5 \\
\hline Temperature Change $\left({ }^{\circ} \mathrm{C}\right)$ & 0.11 & 10 & 16 & 15 \\
\hline Total Phosphate $(\mathrm{mg} / \mathrm{L})$ & 0.10 & 2 & 2 & 2 \\
\hline Nitrates $(\mathrm{mg} / \mathrm{L})$ & 0.10 & 29 & 9 & 8 \\
\hline Turbidity $(\mathrm{NTU})$ & 0.08 & 33 & 41 & 34 \\
\hline Total Solids $(\mathrm{mg} / \mathrm{L})$ & 0.07 & 20 & 20 & 20 \\
\hline & & $\sum \mathbf{W Q I = 2 4}$ & $\sum \mathbf{W Q I = 3 0}$ & $\sum \mathbf{W Q I = 2 6}$ \\
\hline
\end{tabular}

Table.7 Irrigation water quality based on EC (dS/m)

\begin{tabular}{|c|l|l|}
\hline EC $(\mathrm{dS} / \mathrm{m})$ & Water Class & Remarks \\
\hline$<0.25$ & Excellent & Can be used safely \\
\hline $0.25-0.75$ & Good & Can be used with moderate leaching \\
\hline $0.75-2.0$ & Permissible & $\begin{array}{l}\text { Not suitable at } 2 \mathrm{dS} / \mathrm{m} \text { though but can be } \\
\text { used with proper management below } \\
\text { that. }\end{array}$ \\
\hline $2.0-3.0$ & Doubtful & Cannot be used for irrigation \\
\hline$>3.0$ & Unsuitable & Cannot be used for purposes \\
\hline
\end{tabular}

Table.8 Suitability of Manchalapur tank water for irrigation based on SAR

\begin{tabular}{|l|l|l|l|l|}
\hline SAR & Remarks & Pre-monsoon & Monsoon & Post monsoon \\
\hline$<10$ & Little or no hazard & - & $\begin{array}{l}\text { Inlet }-4.42 \\
\text { WS-I }-4.26 \\
\text { WS-II }-4.50 \\
\text { Outlet }-4.15\end{array}$ & $\begin{array}{l}\text { Inlet }-9.80 \\
\text { WS-II }-8.79 \\
\text { Outlet }-8.45\end{array}$ \\
\hline $10-18$ & $\begin{array}{l}\text { Can be used with } \\
\text { appropriate } \\
\text { management } \\
\text { (leaching and } \\
\text { application of soil } \\
\text { amendments) }\end{array}$ & $\begin{array}{l}\text { WS-II - 16.62 } \\
\text { Outlet }-17.15\end{array}$ & - & WS-I - 10.24 \\
\hline $18-26$ & $\begin{array}{l}\text { Unsatisfactory for } \\
\text { most of the crops }\end{array}$ & $\begin{array}{l}\text { Inlet }-18.01 \\
\text { WS-I }-19.30\end{array}$ & - & - \\
\hline$>26$ & $\begin{array}{l}\text { Unsafe for } \\
\text { irrigation }\end{array}$ & - & - & - \\
\hline
\end{tabular}


Table.9 Quality of Manchalapur tank water for irrigation based on $\mathrm{Na} \%$

\begin{tabular}{|l|l|c|c|c|}
\hline $\mathrm{Na} \%$ & Water Class & Pre monsoon (\%) & Monsoon (\%) & Post monsoon (\%) \\
\hline$<20$ & Excellent & - & - & - \\
\hline $20-40$ & Good & - & $\begin{array}{c}\text { Inlet }-28.84 \\
\text { WS-I }-31.08 \\
\text { WS-II }-35.31\end{array}$ & - \\
& & & Outlet -31.05 & \\
\hline $40-60$ & Permissible & Inlet -49.66 & & Inlet -41.67 \\
& & WS-I -54.79 & - & WS-I -48.96 \\
& & WS-II -51.76 & & WS-II -47.53 \\
& & Outlet -51.42 & & Outlet -43.19 \\
\hline $60-80$ & Doubtful & - & - & - \\
\hline$>80$ & Unsuitable & - & - & - \\
\hline
\end{tabular}

Fig.1 A representation on tank (a) inlet showing growth of thorny bushes, (b) outlet, (c) showing algae bloom, concrete failure and weeds in part of water spread area and (d) damaged sluice
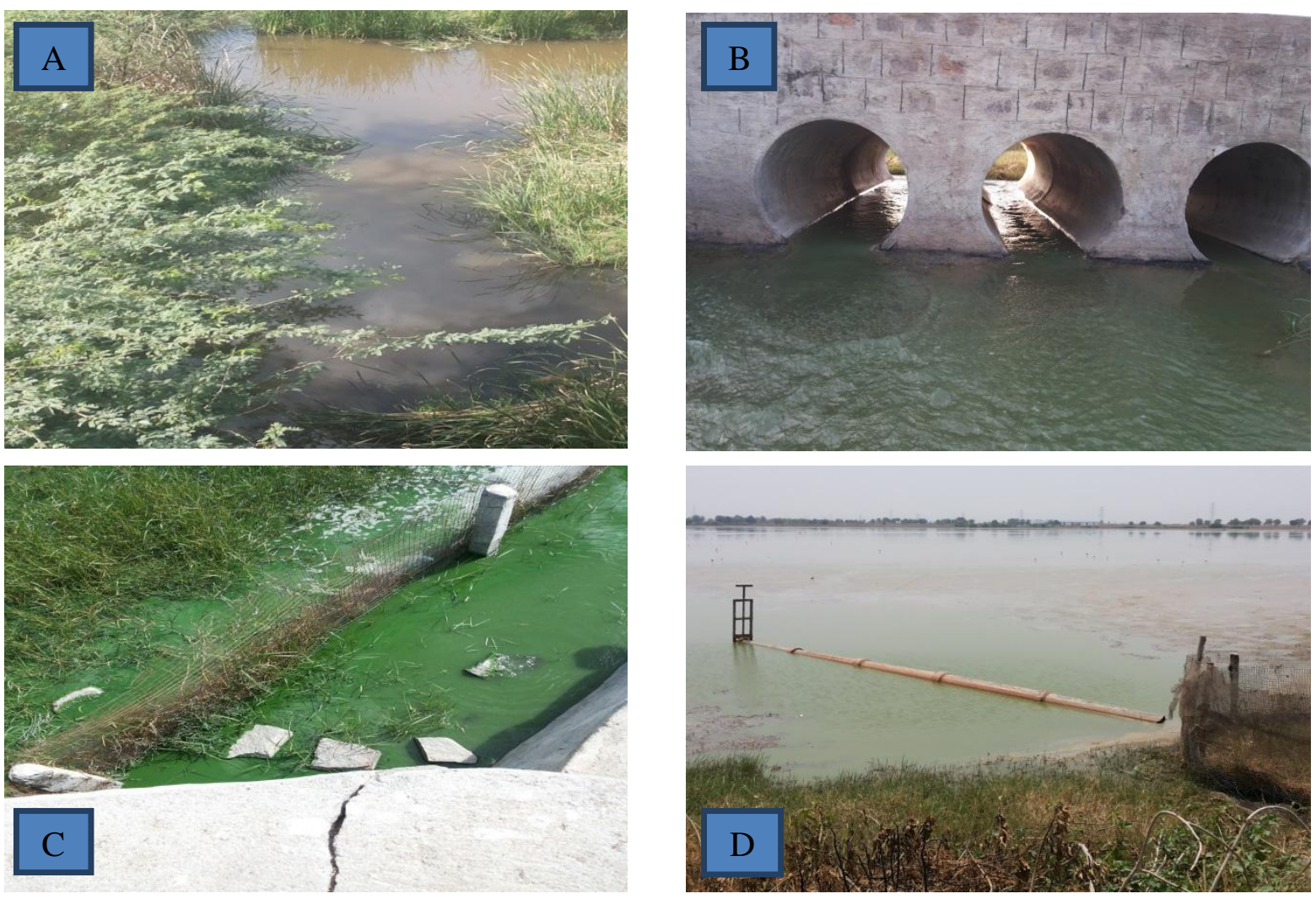
Fig.2 Impacts of tank water irrigation on (a) soil and cotton plantation, (b) paddy field after harvesting and (c) fish die-off observed at inlet of tank
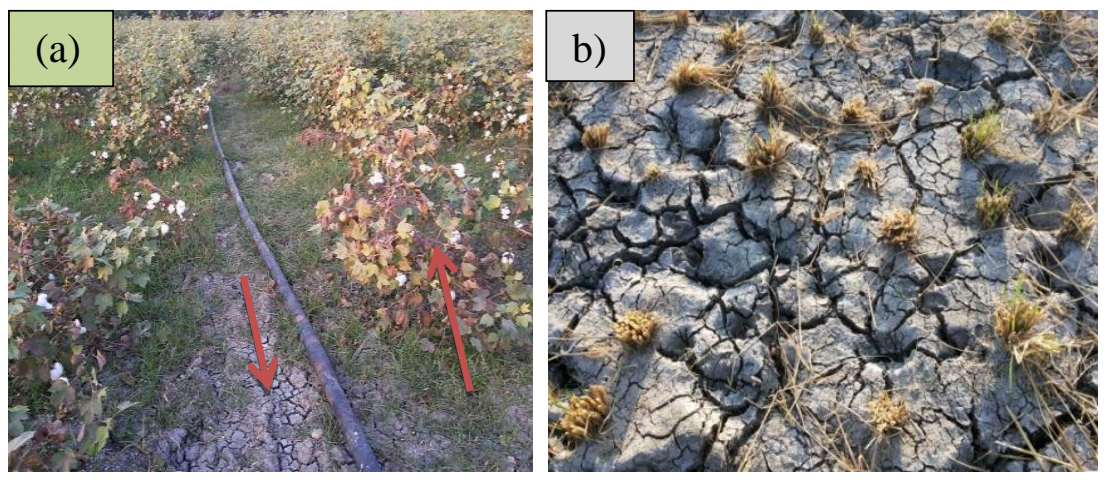



$$
\mathrm{Na} \%=\frac{\left(\mathrm{Na}^{+}+\mathrm{K}^{+}\right) \times 100}{\left(\mathrm{Ca}^{2+}+\mathrm{Mg}^{2+}+\mathrm{Na}^{+}+\mathrm{K}^{+}\right)}
$$

Where all concentrations are expressed in meq/l.

$\mathrm{Na} \%$ measured in water samples from the tank are given Table 9 and indicates good water quality only during the monsoon season based on $\mathrm{Na} \%$. However, the $\mathrm{Na} \%$ measured at all sampling locations in the pre-monsoon season and post monsoon fall within permissible limit.

\section{NPK}

The presence of NPK in irrigation water is largely a fertility issue and the tank water shows appreciable content of NPK especially during the post monsoon season. However, an excess of nutrients in the water system can cause eutrophication and impair aquatic life. Excess nitrogen, at concentrations ranging from 0.1 to more than $1.6 \mathrm{mg} / \mathrm{l}$, in surface waters can cause excessive algae growth, which depletes dissolved oxygen in water and impacts other aquatic species (Tjandraatmandja et al., 2010). Potassium is important for grain formation and is also necessary for tuber development. All root crops generally give response to application of potassium (Rai et al., 2011). Regarding potassium concentrations, tank water can be recommended for irrigation purposes as potassium is essential for protein synthesis, starch formation and for translocation of sugars. Therefore, while the Manchalapur tank water would be a good source of nutrients for plants growth, the excess NPK in the water system would result in algae growth and thus have dire consequences on fish reared in the tank.

\section{BOD $_{5}$}

BOD measured in this study exceeded the maximum permissible limit of $100 \mathrm{mg} / \mathrm{l}$ for irrigation water. According to the $\mathrm{CPCB}$ water quality criteria for propagation of fisheries, the recommended $\mathrm{BOD}_{5}$ of water should be $2 \mathrm{mg} / \mathrm{l}$ or less. Hence, the Manchalapur tank water is not suitable for irrigation and unsupportive for aquatic life based on BOD. Fish mortality was observed at certain locations of the tank in the premonsoon season.

\section{Detergents}

Due to their amphiphilic nature surfactants in raw sewage can adsorb to the surface of resident particulate matter. Surfactants may also precipitate from solution in the presence of metal ions (particularly $\mathrm{Ca}^{2+}$ ). Such behaviour may result in a significant 
proportion of the surfactant load of raw sewage being associated with the particulate fraction. Toxic effects of surfactants are also combined with adsorption tendencies of surfactant molecules. In the concentration range of 1 to $100 \mathrm{ppm}$, surfactants are strongly toxic to fish (Tomiyama, 1975). According to Tomiyama (1975), surfactants are not ingested in the alimentary track of fish but they are adsorbed on gills. They form complex of surfactant and gill proteins disturbs the functioning of gills resulting into oxygen deficit.

\section{Pathogens}

Total coli form and faecal coli form by themselves are usually not pathogenic; they are indicator organisms, which mean they may indicate the presence of other pathogenic bacteria. The presence of coli form in tank water is due to overflow of domestic sewage and non-point sources of human and animal waste. The results from this study showed that E. coli population, both total coliform and faecal coliform, were found to be greater than $1600 \mathrm{MPN} / 100 \mathrm{ml}$ at all sampling locations in the pre-monsoon season. And it varied from $900 \mathrm{MPN} / 100 \mathrm{ml}$ to $1600 \mathrm{MPN} / 100 \mathrm{ml}$ in the monsoon and post monsoon seasons. The presence of coliform contamination indicates that the water has been contaminated with faecal material of man or other animals and this has potential health risks for individuals who may consume fish reared in the tank or crops irrigated with tank water over time.

\section{Exploratory study of Manchalapur tank system and implications on multiple uses}

The Manchalapur tank is subjected to heavy inflow of domestic wastewater from the Raichur city and this is the foremost threat to the multiple uses of tank water. Other threats such as weed growth in supply channel, surplus weir, damaged sluice, and siltation are threats of poor management. It is also observed that weeds have also taken significant part of the tank water spread area.

The tank has one sluice which is damaged, one surplus weir (concrete breaking) and six waste weirs. The waste weirs are rather in good condition. Tank bunds are breached and thorny bushes surrounds tank (Fig. 1). Portions have become breeding sites for mosquitoes. The colour of the Manchalapur tank water appeared light brownish to light greenish. When the flow of water is low it appeared light brownish colour at the inlet and light greenish colour at the outlet and water spread area. Water appears turbid especially during rainy days and at the time of sewage inflow. The greenish colour may indicate the high productivity of the water ecosystem and the presences of high amount of nutrients present in the water that increase the amount of phytoplankton productivity in the water. The brownish colour may be due to the presence of the colloidal particles. The tank water has earthy odour and a cloudy appearance. With lapse of time, due to microbial action, the smell of the water becomes more pronounced.

The tank was originally considered as source of drinking water for man and livestock, washing, pond for pisciculture and irrigation system for crops. However, these uses are limited in number now as uses are now limited to only irrigation and rearing of fish. Large section of the village mass of Manchalapur village in one or other way are facing adverse effects of sewage contamination in terms of health problems and steep decline in agricultural productivity, due to usage of tank water for irrigation. Farmers have, thus, shown great concern and have raised strong objections against the disposal of domestic wastewater from the Raichur city. They have called for appropriate measures to curtail tank water pollution 
within threshold. The City Municipal Corporation, Pollution Control Board, Raichur Office, and Minor Irrigation Office have equally shown concerns about current status of the tank and have suggested that finding a solution to this problem of pollution would go a long to contribute significantly to the livelihood of the Manchalapur people. However, any such initiatives are yet to be undertaken. In India, local level institutions play very crucial role in sustainable management of water systems as well as local farmers who mostly form water user's association. Thus, under current circumstance of accessing the sustainable benefits (multiplicity of uses) and maintaining tank ecosystem services, the tank need high priority attention and management from both the Government officials and the local people.

The tank has a capacity of about 677,740 cum and 1.5 metres deep. The components that make up the inflow into the tank depend on domestic wastewater and runoff resulting from rainfall from its catchment. Kwarteng $e t$ al., (2016) estimated the quantity of sewage inflow and runoff into the tank for the past ten years and projected future expected inflows. They found out the highest ratio of runoff to sewage inflow over the past 10 years to be 31.52 per cent and concluded that with the growth rate of the Raichur city, the sewage inflow is expected to be very high in the near future. This would diminish the dilution ratio and consequently increase the pollution load of tank water. Hence, they underscored the need for urgent attention in curtailing tank water pollution using innovative and sustainable technologies.

\section{Impact on domestic activities}

Water required for drinking and other household activities must be of very high quality due to various associated problems of polluted water source. The estimated WQI for all three sampling seasons indicates that the Manchalapur tank is unsuitable for drinking purpose. Treatment to safe use may not be economically viable as WQI ranging from 0 24 is considered to be beyond treatment measures (Singh et al., 2015) and costs of household WTP for improvements to drinking water quality are typically very expensive (Dodds et al., 2009; Dogot et al., 2010).

Due to the high level of pollution, the people of Manchalapur for some time now have become averse to relying on tank water for domestic purposes. Stink and mosquitoes have driven the village residents away from the tank. As Raichur city expanded with setting up new industries, people from surrounding villages migrated there in search of livelihood. A landfill came up in a nearby village Eklaspur for its solid waste and Manchalapur tank became a disposal point of its liquid waste. Also in recent past, the tank has been subjected to heavy inflow of municipal sewage from Raichur city throughout the year. The bore wells and open wells located in the fringe of the village and in the command area as a result are also subjected to influence of intrusion of seepage from the saline water body which likely pollute the groundwater to a greater degree. There are many reported cases of cancer, arthritis and ailments of nervous system due to consumption of water from wells located in the command area and its fringes. Thus, the village now relies on the Krishna basin as the main source of supply of potable water for the households.

\section{Impact on agriculture (Irrigation, livestock and fishing)}

The dependence on Manchalapur tank water for irrigation is as a result of lack of alternative source of irrigation water. The tank receives concentrated sewage from the Raichur city during summer and diluted 
during monsoon when the rains are expected. Regardless of knowledge of source of inflow into the tank and dangers it may pose, farmers still rely on tank for irrigation and fish farming. Livestock, mostly cattle, trekking to the environs of water body to drink from the pool of water is a rare scene at Manchalapur and this could be as a result of the stink and poor tank water quality.

In a region, where produce in the dry season could be sold at 3 to 5 times the kharif season price (Huibers et al., 2005), tank water comes in handy and allows farming to be done in the dry season irrespective of level of water pollution. This, however, results in great adverse effects as soil under mostly flood irrigation gradually becomes sodic in the process and also resulting in major fish dieoffs as shown in Figure 2. During the monsoon season, tank water is diluted by rainfall-runoff and tank water pollution and thus its negative impacts are quite minimal. Fish harvested during the monsoon season enjoy great market in Mysore and the economic capital Mumbai as per farmer's narration. Farmers as well produce just enough crops to feed their family and sell the rest in the Raichur market. Hence, even though tank water could be relied on for an all year round agricultural production, advice on usage is only favourable during the monsoon season when there is expected dilution by rainfall-runoff.

\section{Strategic measures for sustaining tank water for safe reuse}

Kwarteng et al., (2017) in a study to assess occurrences of drought in Raichur and its environs marked the region to be more vulnerable to drought. This means that incidence of water scarcity in the region is inevitable. This is a major threat to agriculture and could also augment pressure on available water resources. Hence, it is advisable to curtail the pollution level of the Manchalapur tank in order to serve as alternative source of water for economic, domestic and agricultural purposes. And this can be achieved in a more sustainable way by involving all major stakeholders to provide the best outcome for local farmers and the natural environment.

Through this study, the pollution source of the tank through is found to be not only from sewage runoff from the Raichur city but also include anthropogenic activities of the Manchalapur village people such as washing clothes and farming close to the tank although the sewage runoff remains the major pollution source. Hence, minimizing the risk of polluting tank water by preventing direct runoff of sewage from the Raichur city appears to be the foremost technical solution to this problem. This can be achieved by redesigning the entire collection and disposal system of the Raichur city sewerage system (which is defunct currently) including a low energy and cost effective treatment system. Facultative and stabilisation ponds have proven to be cost effective and efficient treatment systems to treat sewage for safe reuse (Hosetti and Frost, 1995; Shukla et al., 2006; Tyagi et al., 2008; Mansouri and Ebrahimpour, 2011; Al-Hashimi and Hussain, 2013). Treated sludge from this treatment system can be put to reuse to improve soil properties at the command area. Quality soil at command can also be achieved by minimising soil degradation and damage to crops by using sustainable irrigation application rates -also employing suitable separation distances for irrigation, based on soil limitations and crop requirements. In order to maximise balanced nutrient status and excessive salt removal, viable and best management practices are to be followed such as the use of chemical ameliorants like gypsum and lime whenever applicable.

Furthermore, conducting training and 
awareness programmes for farmers on water use are to be launched and practiced. This would help prevent adverse health impacts on the public and livestock. This can be complemented with the formation of environmental clubs comprising of the village people, the Raichur district Pollution Control Board and students and professors from the College of Agricultural Engineering (specifically the Soil and Water Engineering department) and College of Agriculture all of the University of Agricultural Sciences, Raichur, for effective water quality and ecological monitoring. Farmers can also benefit from their expertise in the form of education on proper agricultural management practices, water management, modern concepts of agriculture including best irrigation practices and crop type to grow.

The proximity of farming activities to the tank and resultant fertiliser usage also contribute to the pollution of tank water by runoff from the agricultural land. Thus, a buffer zone must be delineated and farmers restricted from farming in this zone. For aesthetic reasons and reduction in evaporation rates, trees preferably those with phytoremediation potential can be planted along this buffer zone.

The water samples from the Manchalapur tank assessed was alkaline in all three sampling seasons as per $\mathrm{pH}$ values measured. The water quality had varied with season with COD, dissolved solids and major ions measuring the highest in the pre-monsoon season, followed by in post-monsoon and least in the monsoon seasons. This is when tank received undiluted sewage from the Raichur city. There is, however, a selfpurification of lake during the monsoon season as lake gets diluted by rainfall-runoff and as a result concentrations of dissolved solids and ions are reduced significantly. $\mathrm{BOD}_{5}$ as well as NPK rather measured highest in the monsoon season and this could be due to high decomposition of organic matter and additional NPK from agricultural lands. There was also the presence of surfactant and high level of coliform in water samples throughout the seasons. Carbonate concentration, however, in all areas was very low. The estimated weighted water quality index were 24, 30 and 26 in pre-monsoon, monsoon and post-monsoon season respectively, indicating high pollution level and thus rendering tank water highly unsuitable for drinking purposes. $\mathrm{BOD}_{5}$, COD, surfactants, excess in NPK, total coliform and faecal coliform were at limits that could have potential deleterious effect on aquatic life. EC, TDS, major ions, SAR and $\mathrm{Na} \%$ measured to assess suitability of irrigation only proved suitable in the monsoon season. Hence, it is concluded that the Manchalapur tank has not outlived majority of its historical purposes other than irrigation which also proved only suitable in the monsoon season.

\section{References}

Al-Hashimi, M. A. and Hussain, H. T., 2013, Stabilisation pond for wastewater treatment. European Scientific J., 9(14): 278-294.

Al-Khashman, O. A., Al-Hwaiti, M., Al-Khatib, L. and Fraige, F., 2013, Assessment and evaluation of treated municipal wastewater quality for irrigation purposes. Research $J$. Environ. Earth Sci., 5(5): 229-236.

Amerasinghe, P., Bhardwaj, R. M., Scott, C., Jella, K. and Marshall, F., 2013, Urban Wastewater and Agricultural Reuse Challenges in India. International Water Management Institute (IWMI) Research Report 147.

American Public Health Association (APHA), AWWA and WPCF, (1998), Standard Methods for Estimation of water and waste water, American Public Health Association, Washington, 20th ed., New York.

Bauder, T. A., Waskom, R. M., Sutherland, P. L. and Davis, J. G. (2014) Irrigation water 
quality criteria. Colorado State University Extension, no. 0.506.

Bhamoriya, V., 2004, Wastewater Irrigation in Vadodara, Gujarat, India: Economic Catalyst for Marginalized Communities. In: Scott CA, Faruqui NI and Raschid-Sally L. (Eds). Wastewater Use in Irrigated Agriculture: Confronting Livelihhod and Environmental Realities. CAB International in Association with IWMI: Colmbo, Sri Lanka, and IDRC: Ottawa, Canada.

BIS (Bureau of Indian Standards) (2012) Indian standard drinking water specification, second revision ISO: 10500:2012, Bureau of Indian Standards. Drinking Water Sectional Committee, FAD 25, New Delhi, India

Buechler, S., Devi, G. and Raschid, L., 2002, Livelihoods and wastewater irrigated agriculture along the Musi river in Hyderabad city, Andhra Pradesh, India. Urban Agriculture, 14-17.

Central Pollution Control Board, 2010, CPCB Report Series: CUPS/70/2009-10. Status of Water Supply, Wastewater Generation and Treatment in Class I Cities and Class II Towns of India. Central Pollution Control Board, India.

Dodds, W. K., Bouska, W. W., Eitzmann, J. L., Pilger, T. J., Pitts, K. L., Riley, A. J., Schloesser, J. T. and Thornbrugh, D. J. (2009), Eutrophication of U.S. Freshwaters: Analysis of potential economic damages, Environmental Science and Technology, 43(1): 12-19.

Dogot, T., Xanthoulis, Y., Fonder, N. and Xanthoulis, D. (2010), Estimating the costs of collective treatment of wastewater: the case of Walloon Region (Belgium). Water Science \& Technology 62(3): 640-648.

Gupta, A. K., Gupta, S. K. and Patil, R. S. (2003). A comparison of water quality indices for coastal water, J. Environ. Sci. Health 38 (11): 2711-2725.

Hosetti, B. B. and Frost, S., 1995, A review of the sustainable value of effluents and sludges from wastewater stabilization ponds. Ecological Engineering, 5(4): 421-431.

Huibers, F. P. and van Lier, J. B., 2005, Use of wastewater in agriculture: The water chain approach, Irrigation and Drainage, 54: 3-9.

Hussain, I., Raschid, L., Hanjra, M. A., Marikar,
F. and van der Hoek, W., 2002, Wastewater use in agriculture: Review of impacts and methodological issues in valuing impacts. Colombo, Sri Lanka: IWMI. Working Paper, 37: 3-12.

Kaur, R., Wani, S. P., Singh, A. K. and Lal, K., 2012, Wastewater production, treatment and use in India, Country Report - India, p 13.

Kwarteng Francis, et al., (2017) Reconnaissance Drought Index as Potential Drought Monitoring Tool in a Deccan Plateau, Hot Semi-Arid Climatic Zone. International Journal of Agriculture Sciences, Volume 9, Issue 1, pp.-2183-2186.

Kwarteng, F., Satishkumar, U., Veeresh, H., Nemichandrappa, M. and Babu, B. M. (2016). Assessing quality and quantification of municipal sewage inflow based on per capita water supply and runoff estimation, Int'l Jr. Agril Sci.\&Res. 6(2): 53-64

Mahuya, D. G. A., Purohit, K. M. and Datta, J. (2001). Assessment of drinking water quality of river Brahmani. Indian J. Environ. Prot., 8, 285-291.

Mansouri, B. and Ebrahimpour, M., 2011, Heavy metals characteristics of wastewater stabilisation ponds. American-Eurasian $J$. Agric. \& Environ. Sci., 10(5): 763-768.

Minhas, P. S. and Samra, J. S., 2004, Wastewater Use in Peri-urban Agriculture: Impacts and Opportunities. Bulletin No. 2, CSSRI, Karnal 132001, India.

Palrecha, A., Kapoor, D. and Malladi, T., 2012, Wastewater irrigation in Gujarat: An exploratory study. IWMI-TATA Water Policy Program. Available at: (www.iwmi.cgiar.org/iwmitata/PDFs/2012_H ighlight-30.pdf)

Raghunath, H. M. (1987) Groundwater. Wiley Eastern Ltd, New Delhi 563

Rai, S., Chopra, A. K., Pathak, C., Sharma, D. K., Sharma, R. and Gupta, P. M. (2011). Comparative study of some physicochemical parameters of soil irrigated with sewage water and canal water of Dehradun city, India. Arch. Appl. Sci. Res., 3(2): 318-325.

Richards, L. A. (1954) Diagnosis and improvement of saline and alkali soils, US Department of Agriculture Handbook, p 60

Rutkowski, T., Raschid-Sally, L. and Buechler, S., 2007, Wastewater irrigation in the developing 
world - Two case studies from the Kathmandu Valley in Nepal. Agricl water manage., 88: 83-91.

Semiromi, F. B., Hassani, A., Torabian, A., Karbassi, A. and Lotfi, F. H. (2011). Evolution ofa new surface water quality index for Karoon catchment in Iran. Water Sci. Technol. 64, 2483-2491.

Shende, G. B., Chakraborti, C., Rai and Nashikar, R. P., 2000, Status of wastewater treatment and agricultural reuse with special references to Indian experience and research and development needs. Proc. FAO Regional Seminar on the Treatment and Use of Sewage Effluent for Irrigation, Nicosia, Cyprus, 7-9, London.

Shukla, S. K., Tripathi, P., Pandey, M., Dubey, A., Mangal, M. S. and Vivek, K., 2006, Treatment of municipal sewage by the combination of anaerobic and facultative treatment process - a case study. Environmental Engineering and Management J., 5(5): 1085-1094.

Singh, S., Ghosh, N. C., Krishan, G., Galkate, R., Thomas, T. \& Jaiswal, R. K. (2015). Development of an Overall Water Quality Index (OWQI) for Surface Water in Indian Context, Current World Environment 10(3): 813-822

Souligny EA, Davidson JD, Martin TD, Mcinnish MB, Schultz BS, Wilson CG, Wood JL, Hollabaugh CL (2001) Sulfate content of surface waters of West Georgia: variations with land usage and flow characteristics of streams in Carroll and Heard Counties, Georgia. The Geological Society of America annual meeting, Paper no: 151.

Srebotnjak, T., Carr, G., de Sherbinin, A. \& Rickwood, C. (2012). A global Water Quality Index and hot-deck imputation of missing data. Ecol. Indic. 17, 108-119.

Srinivasana, J. T. and Reddy, V. R., 2009, Impact of irrigation water quality on human health: A case study in India. Ecological Economics, 68: 2800-2807.

Strauss, M. and Blumenthal, U., 1990, Human Waste Use in agriculture and Aquaculture: Utilization Practice and Health Perspectives. IRCWD Report 09/90. International Reference Centre for Waste Disposal, Duebendorf, Germany.

Suutari, A., 2006, India - East Kolkata - Making the most of it: wastewater, fishponds and agriculture. The EcoTipping Points Project. (http://ecotippingpoints.org/our-stories/ indepth/ india-calcutta-wetland-wastewater-agriculturefishpond.html) (Accessed, 15/09/2017).

Tjandraatmadja, G., Pollard, C., Sheedy, C. and Gozukara, Y. (2010). Sources of priority contaminants in domestic wastewater: contaminant loads from household products, Water for a Healthy Country National Research flagship, CSIRO Publishing.

Tomiyama S., 1975: Fundamental study of biochemical behavior of anionic sulfonate andsulfatetype surfactants, J. Am. Oil Chem. Soc., 52(5), 135-139.

Tyagi, S., Sharma, B., Singh, P. and Dobhal, R. (2013). Water Quality Assessment in Terms of Water Quality Index, American Journal of Water Resources, 1(3), 34-38

Tyagi, V. K., Kazmi, A. A. and Chopra, A. K., 2008, Removal of faecal indicators and pathogens in a waste stabilization pond system treating municipal wastewater in India. Water Environment Research, 80(11): 2111-2117.

\section{How to cite this article:}

Francis Kwarteng, Umapathy Satishkumar, Moddi Nemichandrappa, Banda Maheshwara Babu and Veeresh Hogarnal. 2017. Seasonal Variation and Hydro-chemical Characterization of Manchalapur Lake Quality for Drinking and Agricultural Purposes. Int.J.Curr.Microbiol.App.Sci. 6(11): 990-1007. doi: https://doi.org/10.20546/ijcmas.2017.611.116 